\title{
Ergonomics Review : Identify Discomfort Seating Posture Among Elderly Taxi Drivers at Malaysia Perspective.
}

\author{
Ahmad Zuhairi Abdul Majid ${ }^{1}$, Irwan Syah Md Yusoff ${ }^{2}$, Shamsul Bahri Mohd Tamrin ${ }^{3}$ \\ ${ }^{1}$ School of Arts, Universiti Sains Malaysia, Pulau Pinang, Malaysia \\ ${ }^{2}$ School of Arts, Universiti Sains Malaysia, Pulau Pinang, Malaysia \\ ${ }^{3}$ Faculty of Medicine and Health Science, Universiti Putra Malaysia, Serdang, Malaysia \\ zuhairi.majid@usm.my, c_ton83@yahoo.com, uvea_2000@yahoo.com
}

\begin{abstract}
World Health Organization (WHO) describes people aged above 60 years old fall under a category of elderly. The alternative profession could involve with this community is to be taxi drivers. Therefore, numerous factors should take part to ensure the elderly taxi drivers could serve their best performance and in good health condition. This study aimed to determined discomfort seating posture among elderly taxi drivers through ergonomic approach in Malaysian perspective. A cross-sectional study was conducted with elderly taxi drivers using a self-administered questionnaire. It included questions on socio-demographic data, work characteristics and discomfort older taxi drivers seating posture relative to body parts. Purposive method sampling used base on inclusive criteria; age 60 years old and above, self -driving taxi more than 1 year, no disabilities and registered with Land Public Transport Commission (LPTC). Total of 120 respondents participated in the study. Most of elderly taxi drivers used hired car type of taxi and work as a permanent job. The highest feeling discomfort on seating body posture among elderly taxi drivers are at the right hips and left buttock. At the left hips and lower back showed the highest discomfort on seating posture compare to other body parts. Inappropriate seating posture among elderly taxi drivers may cause to discomfort and developing to MSD's. The low awareness on ergonomics education could reflect quality lifestyle and health among elderly taxi drivers in Malaysia.
\end{abstract}

Keywords elderly, taxi driver, seating posture, ergonomics, discomfort

\section{Introduction}

Malaysia's population in the year 2016 was approximately 31.7 million with 0.5 million increased as compared to the year 2015 which was 31.2 million with 1.5 per cent population growth rate (DOSM, 2016). This number will be continued rising year by year to achieve vision 2020. A statistic from Department of Statistics Malaysia (DOSM, 2016) showed population aged 65 years and above increased by 0.2 percentage points from 5.8 percentage (2015) to 6.0 percentage and equivalent to 1.9 million elderly communities in Malaysia for the year 2016. World Health Organization (WHO) described people who age above 60 years old falls into a category of elderly. Besides that, elderly people need specific consideration to sustain their life according to ability and capability in the challenging world. The characteristic of elderly people may different to other ages in terms of physiological, sensory, perceptual, motor and cognitive abilities that may impact on how elderly interact with task and behaviour (Herriot P. et al. 2005). These changes would decrease elderly in ability, strength, reduced ability to process information; slowed reaction and hearing loss (Smith et al., 1993). The limited ability among elderly could react to their lifestyle and health also safety on driving behaviour. The research was conducted by Smith et al. 1993, transportation is a key to a life of quality and wellbeing for elderly and this has come to mean access to the private car. Past research indicated that approximately onethird of pensioners are vulnerable to poor retirement and outcomes in term of life satisfactions and well-being (Van Solinge and Henkens,2008; Wang et al. 2007).

Therefore, an elderly community may continue to serve their services to others jobs after pension or looking light 
works accordance to their ability or do as a part time jobs to support family economic financial and to sustainable life in the challenging world. The alternative professions could involve these communities are to be a taxi driver. Many factors influenced elderly people to choose to be a taxi driver; to sustain life due to limited ability and capability in challenging world, light job and easy to handle, less energy, low cost, no specific requirement (standard licensed), no specific regulation (Malaysian laws) and has driving experience on commercial or private car. In peninsular Malaysia in the year 2013 total of 60,472 taxi drivers there are 59,174 (98\%) male drivers and only 1,298 (2\%) female taxi drivers (SPAD, 2013). According to data in the year 2014 from Land Public Transport Commission (LPTC), approximately 64,547 registered taxi drivers in Malaysia. This number will rise year by year and population taxi driver under category elderly also will increase. Therefore, numerous factors should take part to ensure the elderly taxi drivers could serve their services at high performance and insurance their life in good health. First is the time factor; taxi drivers spend a longer time in driving than other professions (Raanaas and Anderson 2008; Talamanca et al., 1996; Dalziel and Rob 1997). Second factor is baggage handling exceeds body limit and sleeping on the car seat in confined space during rest breaks (Raanaas and Anderson 2008).

Over exposed driving in term of distance and hours to elderly taxi drivers caused many negative impacts. Hence, the characteristic of elderly taxi driver it so crucial to understand, it may causes of the aging process make elderly people more vulnerable to injury. Structure body elderly is too fragile compared to an adult, it takes less energy to produce tissue damage and disruption, and their skeletal structures are more easily damaged through bone loss. Due to that, sitting which is the work posture of a driver should be properly done to avoid injuries among elderly taxi drivers. A previous study found on driver fatigue and low back pain disorders as a matter of research and development, however, the need for users assessment of seat design is inevitable (Park et al. 1998). Car seat design and arrangement seat play important to human body specifically on health. Numerous of complaints obtained from past researchers, taxi drivers are related to musculoskeletal disorders (MSD's) especially on low back pain (Sami Abdo Radman Al Dubai et al., 2012; Burgel et al., 2012; Yang Y et al.,2014; Nahar et al., 2012; M.A Machin \& J.M.D. De Souza, 2004). Seated posture as potentially unhealthy and considered as one of the major contributing factors for several MSD's such as pain in the lower back part (Ebe and Griffin, 2001, neck (Schneider an Ricci, 1989) and shoulder (Magnusson and Pope,1998). Due to increased exposures to seated posture in the car, the proper sitting adjustment has become an important issue that demands adequate ergonomic interventions (Dunk and Callaghan,2005). The sitting while driving needs to be differentiated from the comfort of sitting on a chair at various of an environment such as at home, in the office or at the workplace and factory or others industry. According to Andreono et al.(2002), driver's seat comfort in a car has distinctive comfort value compared to others types of seats. The drivers can show naturally discomfort if his/her body feel pressured, burdened and emotion destruction. Research conducted by Baba Md Deros et al. 2015, adjustability of the driver's seat was the most cited parameter to increase the safety and comfort level. At the worst situation, elderly drivers will feel pain and injury at upper torso body part especially lower back body part. The elderly body muscle fragile and easy to obtain injury and takes time to recover compared to younger people. Emphasizing the ergonomic principles on car seat design would minimize potential MSD's and increased health level between elderly taxi driver.

Ergonomics is basically the applications of science in human life for comfort and safety. The most important contribution that ergonomics can provide to the automobile design process is information of the physical size of driver, and his/her preferred postures (Porter et al., 1998). A comfortable and safe driver's seat plays a very important role in car design and fabrication. Current bundling of the knowledge on comfort and discomfort has been limited, while the need for this knowledge is crucial since people use products related to comfort every day (Vink et al., 2012). The ergonomics of seat comfort has been studied from a number of different perspectives (Zhang et al., 1996; Yamazaki, 1992). According to Baba Md Deroes et al. 2015, the comfort and safety level of the present driver's seat by identifying and determining parameters which influence the comfort level and safety system of the driver's seat. The application of ergonomics in ensuring comfortable and safe posture for elderly taxi drivers to ensuring better lifestyle and safety and health improving.

One of the frequent injuries related on MSD's occurs among professional driver are back pain, neck and related on upper torso body part. About $80 \%$ of drivers will experience back pain at some stage in lives (Robb et al., 2007). A number of work and leisure activities can contribute to back pain and spend long hours driving on static posture may suffer from prolonged discomfort of pain in the back body part and upper torso body part. Sitting in the same position for long hours gripping the steering wheel and being exposed to vibration from the road can contribute to the wear and tear on the back body part. Driving creates significant stress to the neck and the upper and lower back.

\section{Objectives}

This study aimed to explore the discomfort seating posture among elderly taxi drivers at Malaysian perspective through ergonomic review. 


\section{Methods}

The design of this study was a cross - sectional survey using a questionnaire to investigate characteristics of driving background and prevalence of discomfort on seating posture among elderly taxi drivers in Peninsular Malaysia. The study was conducted around rural and urban area at four regions of peninsular Malaysia. A purposive sampling was chosen and 120 respondents participate in the study. Criteria sample has been choose; age above 60 years old, driving experience at least 1 years to be taxi drivers, registered with LPTC, who had a history of major surgery or history of neurological problems were excluded. The taxi drivers was attended any courses or training related with occupational health and also making part time job as taxi drivers and driving less than 4 hours per -day were excluded. Types of taxi services involve only budget car and hired car. Every respondents in peninsular Malaysia age into 60 years above drive taxi budget and hired car with standard seat design without modified the seat drivers are involves directly into study. A small token offered as an acknowledgment in the form of gifts for those completed the survey. The survey took approximately $10 \quad-15$ minutes per- person to complete. The participants were asked kindly and if they agree, then complete information related to work characteristics, some health issues of taxi drivers and seating posture was given.

A self- administered questionnaire which was designed and distributed to the participants. The interview was conducted one to one elderly taxi drivers to obtain good result and minimize miss-interpretation. The question divided into three sections. The first part of the questionnaire included questions on socio-demographic factors (age, race, marital status, education level, status jobs, income, smoking and etc.) and past medical history. The second part included questions on characteristics of elderly taxi drivers such as total pick up passenger perday, resting time, working hours, years as a taxi driver, type employment, total distance driving per-week, regular time start driving, working until late night, competency confident level of driving, feeling back pain last 12 month and past 7 days and type of activities on leisure time. The third part includes questions on the body part discomfort map from each body part on the sitting driving position. The modified questions adapt and adopt from the United States driving ergonomics program. A body part discomfort map diagram of 28 body parts divided into neck, upper back, middle back, left elbow, right elbow, lower back, left buttock, right buttock, left hip, right hip, left thigh, right thigh, left knee, right knee, left calf, right calf, right foot, left foot, stomach, right forearm, left forearm, right wrist, left wrist, chest, right upper arm, left upper arm, right shoulder and left shoulder to assist the elderly taxi drivers in identifying the correct body parts in answering the questions. The questions utilized a simple phrase such as "Within last week did you feel any discomfort on any body parts during driving (works); 1) very uncomfortable; 2) less uncomfortable; 3) uncomfortable; 4) comfortable; 5) very comfortable " and score value begin from 1 to 5 as shown in Figure 1 .

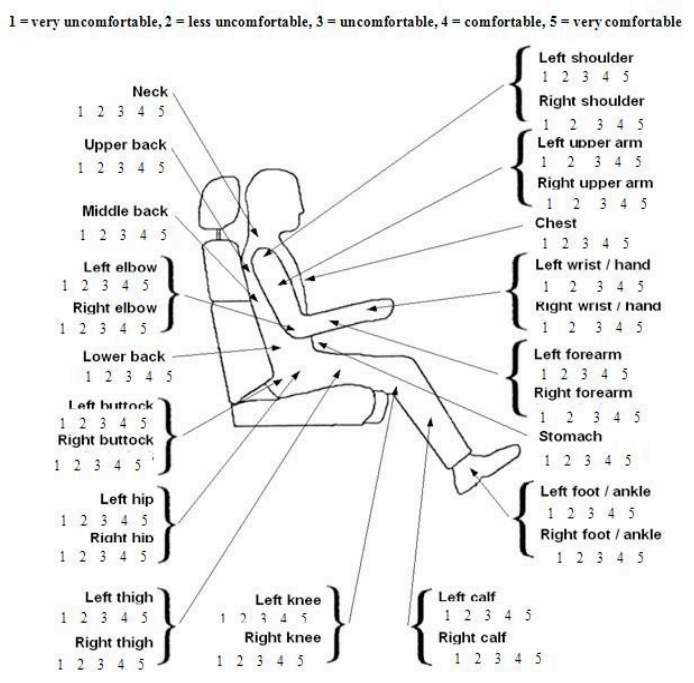

Figure 1. Discomfort body parts maps - adopted from United States driving ergonomics program.

Interview were conducted in parking places bus station, train station, shopping malls, taxi station and business centre area in rural and urban attraction to the public area or main city or town. The analysis was performed using Social Package for Social Sciences (SPSS) software version 20. Descriptive statistics were obtained for all the variables in the study.

\section{Results}

\section{The Background of elderly taxi drivers}

Majority (76.7\%) elderly drivers used hired car as a type of taxi. All respondents were male. Mean $( \pm S D)$ age of the respondents was $64.7 \pm 4.0$ years and age ranged from 60 to 77 years old. Most of elderly taxi drivers were aged between 60 to 65 years old $(60 \%)$. Mean $( \pm \mathrm{SD})$ weight and height respondents was $72.9 \pm 12.2 ; 168.0 \pm 6.7$ and BMI was overweight $(42.5 \%)$. The majority was Malay $(78.3 \%)$ second was India $(13.3 \%)$, married $(98.3 \%)$, secondary school $(60.8 \%)$ for education level. The majority $(93.3 \%)$ of respondents work as full-time taxi drivers and selfemployed (56.7\%). Mean income per-month RM $1383.3 \pm 874.3$ from RM200 to RM4000. Health status was just average $(45.0 \%)$ condition. The smoking status almost equal between answer yes or frequent $(55.0 \%)$ and no or never $(45.0 \%)$. The details background elderly taxi drivers are showed in Table 1. 
Characteristics elderly taxi drivers.

Average mean driving per- week was $30.5 \pm 21.0$ from 8 times to 200 times per week. Half $(52.5 \%)$ of elderly taxi drivers take rest in a week and majority $(84.2 \%)$ of them total hours driving per-day more than 8 hours and average hours driving more than 56 hours per-week. More than half $(67.5 \%)$ elderly taxi drivers not prefer taking nap during waiting turn to obtain passenger and $50.8 \%$ spend within two to three hours and $41.7 \%$ spent more than four hours per-day to obtain customer. Distance driving in perweek more than $250 \mathrm{~km}$ was $75.8 \%$. Less than half (45.8\%) never drive taxi until mid-night. However, only $15.8 \%$ will stay until mind-night. Over than $76.7 \%$ complained having back pain last 12 months and also $67.5 \%$ reported feeling back pain past 7 days. The taxi drivers agreed $(89.2 \%)$ that the feelings of back pain were caused by their work environment. Most of them always (95.0\%) carry passengers' luggage into car and luggage carried was more than $11 \mathrm{~kg}(60.8 \%)$. Table 2 reported total highest driving experiences as taxi drivers were $44.2 \%$ which is more than 16 years. $59.2 \%$ reported that they obtained more passengers five years ago than the current year.

Tables 1, Background elderly taxi drivers.

\begin{tabular}{|c|c|c|c|c|}
\hline Factors & $\mathbf{N}(\%)$ & $\begin{array}{l}\text { Mean } \\
\pm(\text { S.D })\end{array}$ & Min & Max \\
\hline \multicolumn{5}{|l|}{ Category taxi } \\
\hline Hired car & $92(76.7)$ & & & \\
\hline Budget & $28(23.3)$ & & & \\
\hline Gender - Male & $120(100)$ & & & \\
\hline Age & & $64.7 \pm 4.0$ & 60 & 77 \\
\hline $60>65$ & $72(60)$ & & & \\
\hline$>66$ & $48(40)$ & & & \\
\hline Weight & & $72.9 \pm 12.2$ & 49 & 105 \\
\hline Height & & $168.0 \pm 6.7$ & 154 & 188 \\
\hline \multicolumn{5}{|l|}{ BMI } \\
\hline Underweight & $3(2.5)$ & & & \\
\hline Normal & $50(4.7)$ & & & \\
\hline Overweight & $51(42.5)$ & & & \\
\hline Obese & $16(13.3)$ & & & \\
\hline \multicolumn{5}{|l|}{ Ethnicity } \\
\hline Malay & $94(78.3)$ & & & \\
\hline India & $16(13.3)$ & & & \\
\hline
\end{tabular}

$\begin{array}{cc}\text { Chinese } & 10(8.3) \\ \text { Marital status } & \\ \text { Married } & 118(98.3) \\ \text { Divorce } & 2(1.7)\end{array}$

\section{Education}

None $\quad 8(6.7)$

Primary school $\quad 39(32.5)$

Secondary $\quad 73(60.8)$

\section{Current jobs}

Full time $\quad$ 112(93.3)

Part time $\quad 8(6.7)$

Jobs sectors

Company 52(43.3)

Self - $\quad 68(56.7)$

employed

Income per-month

$\begin{array}{ccc}1383.3 \pm 874 & 200 \quad 4000\end{array}$

Health status

$\begin{array}{cc}\text { Good } & 47(39.2) \\ \text { Very good } & 2(1.7) \\ \text { Average } & 54(45.0) \\ \text { Not good } & 17(14.2)\end{array}$

\section{Smoking status}

Yes/frequent 66(55.0)

No/never $54(45.0)$

$\mathrm{N}=120$

Tables 2, Characteristics elderly taxi drivers.

\begin{tabular}{ccccc}
\hline Factors & $\mathbf{N}(\%)$ & $\begin{array}{c}\text { Mean } \\
\pm(\text { S.D) }\end{array}$ & Min & Max \\
\hline Average driving per-week & $\begin{array}{c}30.5 \pm 2 \\
1.0\end{array}$ & 8 & 200 \\
& & &
\end{tabular}

Take rest per-week

$$
\begin{array}{ll}
\text { Yes } & 63(52.5) \\
\text { No } & 57(47.5)
\end{array}
$$

Total hours driving per-day

$\begin{array}{ll}\text { 1>7hours } & 19(15.8) \\ >8 \text { hours } & 101(84.2)\end{array}$

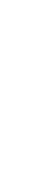

Tables 1, Cont. 
Average hours driving per-week

$$
\begin{array}{cc}
48-56 \text { hours } & 15(12.5) \\
>56 \text { hours } & 105(87.5)
\end{array}
$$

Sleep nap waiting passenger

$$
\begin{array}{ll}
\text { Yes } & 39(32.5) \\
\text { No } & 81(67.5)
\end{array}
$$

Waiting hours passenger per-day

$$
\begin{array}{ll}
<1 \text { hours } & 9(7.5) \\
\text { 2>3hours } & 61(50.8) \\
>4 \text { hours } & 50(41.7)
\end{array}
$$

\section{Average distance driving per-week}

$$
\begin{array}{cr}
51>150 \mathrm{~km} & 4(7.5) \\
151>250 \mathrm{~km} & 25(20.0) \\
>250 \mathrm{~km} & 91(75.8)
\end{array}
$$

Driving until mid-night

$$
\begin{array}{cc}
\text { Always } & 19(15.8) \\
\text { Not frequent } & 46(38.3) \\
\text { Never } & 55(45.8)
\end{array}
$$

Past 12 month feeling back pain

$$
\begin{array}{ll}
\text { Yes } & 92(76.7) \\
\text { No } & 28(23.3)
\end{array}
$$

Past 7 days feeling back pain

$$
\begin{array}{ll}
\text { Yes } & 81(67.5) \\
\text { No } & 39(32.5)
\end{array}
$$

Feeling back pain cause of job

$$
\begin{array}{ll}
\text { Yes } & 107(89.2) \\
\text { No } & 13(10.8)
\end{array}
$$

Carry luggage into boot

$$
\begin{array}{lr}
\text { Yes } & 114(95.0) \\
\text { No } & 6(5.0)
\end{array}
$$

Load luggage weight

$$
\begin{array}{lr}
1>5 \mathrm{~kg} & 7(5.8) \\
6>10 \mathrm{~kg} & 34(28.3) \\
>11 \mathrm{~kg} & 73(60.8) \\
\text { Never } & 6(5.0)
\end{array}
$$

Total driving experience
Tables 2, Cont.

Tables 2, Cont.

$$
\begin{array}{ll}
1>5 \mathrm{yrs} & 32(26.7) \\
6>15 \mathrm{yrs} & 35(29.2) \\
>16 \mathrm{yrs} & 53(44.2)
\end{array}
$$

Compare 5 years driving and current

$$
\begin{array}{cr}
\text { More driving } & 9(7.5) \\
\text { No changes } & 40(33.3) \\
\text { Less than before } & 71(59.2)
\end{array}
$$

$\mathrm{N}=120$

Result from table 3 showed, the highest body part complaints received are the very uncomfortable on driving posture among elderly taxi drivers were left hips (25.0\%) second highest were right buttock $(24.2 \%)$ followed by lower back and right hips $(23.3 \%)$ and body part likes left buttock $(16.7 \%)$, right calf $(14.2 \%)$, upper back and left calf $(12.5 \%)$ but still showed higher complaints under the category of very uncomfortable compared to others body parts. However, $48.0 \%$ feel uncomfortable at body part left buttock second highest on same category are right hips (47.5\%)followed by left hips (44.2\%), lower back (40.0\%), right buttock $(38.3 \%)$ and also upper back and left calf $(33.3 \%)$ and center back and right calf $(32.5 \%)$ received complained with same category. Meanwhile, others body part also reported higher from $35.0 \%$ to $30.0 \%$ by elderly taxi drivers feeling uncomfortable are upper back, center back, neck, left knee, right knee and right shoulder compared to others body parts under same category. In other words, the majority of elderly taxi drivers agreed (92.5\%) the discomfort at body parts happen cause of car seat design. Other body parts complained are showed in Table 3.

Tables 3, Characteristics elderly taxi drivers.

\begin{tabular}{lcc}
\hline \multicolumn{1}{c}{ Factors } & N(\%) & Percentage (\%) \\
\hline Neck & 13 & 10.8 \\
very uncomfortable & 22 & 18.3 \\
less uncomfortable & 42 & 35.0 \\
uncomfortable & 31 & 25.8 \\
comfortable & 12 & 10.0 \\
very comfortable &
\end{tabular}

\section{Upper back}

$\begin{array}{lcc}\text { very uncomfortable } & 15 & 12.5 \\ \text { less uncomfortable } & 40 & 33.3 \\ \text { uncomfortable } & 43 & 35.8 \\ \text { comfortable } & 17 & 14.2 \\ \text { very comfortable } & 5 & 4.2\end{array}$


Center back

$\begin{array}{lcc}\text { very uncomfortable } & 14 & 11.7 \\ \text { less uncomfortable } & 39 & 32.5 \\ \text { uncomfortable } & 43 & 35.8 \\ \text { comfortable } & 22 & 18.3 \\ \text { very comfortable } & 2 & 1.7\end{array}$

\section{Left elbow}

very uncomfortable

Less uncomfortable

uncomfortable

comfortable

very comfortable

\section{Right thighs}

very uncomfortable

less uncomfortable

uncomfortable

comfortable

very comfortable

Left knee

very uncomfortable

less uncomfortable

uncomfortable

comfortable

very comfortable
Tables 3, Cont.

very comfortable

\section{Right buttock}

$\begin{array}{lcc}\text { very uncomfortable } & 29 & 24.2 \\ \text { less uncomfortable } & 46 & 38.3 \\ \text { uncomfortable } & 28 & 23.3 \\ \text { comfortable } & 15 & 12.5 \\ \text { very comfortable } & 2 & 1.7 \\ \text { Left hips } & & \\ \text { very uncomfortable } & 30 & 25.0 \\ \text { less uncomfortable } & 53 & 44.2 \\ \text { uncomfortable } & 21 & 17.5 \\ \text { comfortable } & 16 & 13.3 \\ \text { very comfortable } & 0 & 0\end{array}$

\section{Right hips}

$\begin{array}{lll}\text { very uncomfortable } & 28 & 23.3\end{array}$

$\begin{array}{lll}\text { less uncomfortable } & 57 & 47.5\end{array}$

$\begin{array}{lll}\text { uncomfortable } & 19 & 15.8\end{array}$

$\begin{array}{lll}\text { comfortable } & 14 & 11.7\end{array}$

very comfortable

\section{Left thighs}

$\begin{array}{lll}\text { very uncomfortable } & 13 & 10.8\end{array}$

$\begin{array}{lll}\text { less uncomfortable } & 34 & 28.3\end{array}$

$\begin{array}{lll}\text { uncomfortable } & 30 & 25.0\end{array}$

$\begin{array}{lll}\text { comfortable } & 33 & 27.5\end{array}$

$\begin{array}{lll}\text { very comfortable } & 10 & 8.3\end{array}$

\section{Right knee}

very uncomfortable

less uncomfortable

uncomfortable

comfortable

very comfortable

very comfortable

.8

\section{Left buttock}

\section{Left calf}

very uncomfortable $\quad 15$

less uncomfortable

uncomfortable

comfortable

very comfortable

10.8 
Right calf

Tables 4, Cont.

Tables 5, Cont.

very comfortable

59

$\begin{array}{lcc}\text { very uncomfortable } & 17 & 14.2 \\ \text { less uncomfortable } & 39 & 32.5 \\ \text { uncomfortable } & 20 & 16.7 \\ \text { comfortable } & 31 & 25.8 \\ \text { very comfortable } & 13 & 10.8\end{array}$

\section{Left shoulder}

very uncomfortable

less uncomfortable

uncomfortable

comfortable

very comfortable

38

\section{Right shoulder}

very uncomfortable

less uncomfortable

12

10.0

uncomfortable

$$
36
$$

comfortable very comfortable

$43 \quad 35.8$

Tables 5, Characteristics elderly taxi drivers. (sides)

\begin{tabular}{lll}
\hline Factors & N(\%) & Percentage (\%) \\
\hline
\end{tabular}

\section{Upper wrist left side}

very uncomfortable

less uncomfortable

11.7

uncomfortable

comfortable

very comfortable

44

36.7

Upper wrist right side

very uncomfortable

less uncomfortable

uncomfortable

comfortable

very comfortable

48

40.0

\section{Chest}

very uncomfortable
less uncomfortable
uncomfortable
comfortable

12

\section{Left wrist}

$\begin{array}{lcc}\text { very uncomfortable } & 9 & 7.5 \\ \text { less uncomfortable } & 9 & 7.5 \\ \text { uncomfortable } & 25 & 20.8 \\ \text { comfortable } & 28 & 23.3 \\ \text { very comfortable } & 49 & 40.8\end{array}$

\section{Right wrist}

$\begin{array}{lcc}\text { very uncomfortable } & 10 & 8.3 \\ \text { less uncomfortable } & 9 & 7.5 \\ \text { uncomfortable } & 27 & 22.5 \\ \text { comfortable } & 28 & 23.3 \\ \text { very comfortable } & 46 & 38.3\end{array}$

\section{Left arm}

$\begin{array}{lcc}\text { very uncomfortable } & 12 & 10.0 \\ \text { less uncomfortable } & 7 & 5.8 \\ \text { uncomfortable } & 18 & 15.0 \\ \text { comfortable } & 34 & 28.3\end{array}$

very comfortable

\section{Right arm}

$\begin{array}{lcc}\text { very uncomfortable } & 14 & 11.7 \\ \text { less uncomfortable } & 7 & 5.8 \\ \text { uncomfortable } & 13 & 10.8 \\ \text { comfortable } & 38 & 31.7 \\ \text { very comfortable } & 48 & 40.0\end{array}$

\section{Left ankle}

very uncomfortable

less uncomfortable

uncomfortable

comfortable

very comfortable

\section{Right ankle}

very uncomfortable

less uncomfortable

uncomfortable

comfortable

very comfortable 
Table 6, Discomfort body part cause of seat design

\begin{tabular}{ccc} 
Factors & $\begin{array}{c}\text { Table 6, Discomfort body part cause of seat design } \\
\text { Percentage(\%) }\end{array}$ \\
\hline Yes & N (\%) & 111 \\
No & 9 & 92.5 \\
N=120 & & 7.5
\end{tabular}

\section{Discussion and Conclusion}

This study found the ethnicity population may have different genetics factors, these theory supported from previous study among tractor drivers in Brazil (Andrusaitis et al., 2006), bus drivers (Rozali et al., 2009) and military armoured vehicles drivers in Malaysia (Tamrin et al.,2007) found no significant association between ethnicity and MSD's problem. Majority elderly taxi drivers work as full time and self-employed to sustain their life and family well-being, similar to previous studies taxicabs in Nigeria which are $85 \%$ of taxi drivers engaged in business driving as means of living (Onawumi et al. 2012). Result income per month elderly taxi drivers in Malaysia RM 1383.00 showed different study ALDubai et al. 2012, taxi drivers income in Malaysia more than RM 2000.00. The smoking result not much different with the previous study (AL-Dubai et al., 2012).

In this study, higher developing of body posture risk was found among those who worked more than eight hours daily compared to those driving less working hours. This finding was consistent with that found by Miyamoto et al. 2008, driving long hours. More times spend to pickup and waiting for passenger daily or per-week lead to low back pain injury (Miyamoto et al. 2008). Researcher Tamrin et al. 2007 stated, monotones in long distance driving influenced to factors lower back pain and others injury related to MDS's which means this result showed $75.8 \%$ elderly taxi drivers driving more than $250 \mathrm{~km}$ per week it may potentially lead to developing body muscle problem. The study found that the past 12 month having back pain among taxi drivers in Malaysia was $76.7 \%$ and the past seven days $67.5 \%$ and discomfort body part maps showed back body parts have higher complaints with pain and very discomfort compared to others parts; similar to that was also found in previous research in Japan and Taiwan, which the prevalence of lower back parts among taxi drivers was $45.8 \%$ and $51 \%$ respectively (Funakoshi et al., 2003 Chen et al. 2005). Long experiences of working as taxi drivers related to discomfort in this study as elderly drivers within 6 years to 15 years driving may potential to have a problem on body parts. The previous study among professional drivers found a significant association between low back parts and duration of employment as a bus driver (Tamrin et al., 2007). However, some author studies on taxi drivers did not find such relationship (Chen et al., 2005).
In this study, discomfort on driving sitting body posture among elderly taxi drivers showed right buttock, left buttock, lower back, neck, center back and upper back, left hips, left thighs falls under category very uncomfortable and uncomfortable. It describes all body parts at back side which contact to the seat potentially has the problem on MSDs and lead to developing injury on low back pain. According to Mohammad D. et al. 2016, comfortable car seat driving able to achieve through dimensioning of car set design and should appropriate with anthropometry dimension of the user. In others word, comfortable sitting driving could reduce health problem and develop MSDs on cumulative. Previous studies found a significant association between low back parts and certain ergonomics factors such as the use of backrest support and driving in forward bending sitting posture (Chen at al., 2005; Romli et al., 2009).

Majority elderly taxi drivers agree that this discomfort attributed of mismatch between anthropometry measurement and car seat dimensions and also selective design factors. The previous study was done by Baba Md

Deros et al. 2015, driver's seat design awareness which influenced the perception of drivers comfort and discomfort. In general, this study give us the preliminary perspective of characteristics taxi drivers among elderly especially to identify which body parts potentially may cause to injury or pain on sitting posture among elderly taxi drivers in Malaysian. It also help us in the beginning to prevent MSDs or developing body parts injury through determining which body part potentially may develop the cumulative injury. However, this result only can use a baseline to investigate more details and give us some concrete base to do further study on this topic. The insufficient sample size may effect

to the result for represent population elderly taxi driver in Malaysia. More explore to investigate this topic will benefit to taxi drivers especially elderly community to improve their life and safety and also reduce problem-related to work

MDS's through ergonomics intervention approach in the further study.

\section{ACKNOWLEDGMENTS}

We would like to thank you to the Malaysian Consumer and Family Economics Association (MACFEA) for giving the Mini Grants MACFEA 2017 scheme for this study. In addition, the authors also thanks to the Dean of School of Arts, University Sains Malaysia for supporting this paper to be presented at Bandung Creative Movement International Conference 2017. The contents of this paper are solely the responsibility of the authors and do not necessarily represent the official views of the sponsor.

\section{REFERENCES}

[1] Andreoni, G., Santambrogio, G. C., Rabuffetti, M., \& 
Pedotti, A. (2002). Method for the analysis of posture and interface pressure of car drivers. Applied ergonomics, $33(6), 511-522$.

[2] Andrusaitis, S. F., Oliveira, R. P., \& Barros Filho, T. E. P. (2006). Study of the prevalence and risk factors for low back pain in truck drivers in the state of São Paulo, Brazil. Clinics, 61(6), 503-510.

[3] AL-Dubai, S. A. R., Qureshi, A. M., Ismail, N. H., \& Rampal, K. G. (2012). Prevalence and determinants of low back pain among taxi drivers in Malaysia. A cross sectional study. Journal of Advanced Medical Research,2(4), 129-43.

[4] Chen, J. C., Chang, W. R., Chang, W., \& Christiani, D. (2005). Occupational factors associated with low back pain in urban taxi drivers. Occupational Medicine, 55(7), $535-540$.

[5] DEPARTMENT OF STATISTICS, MALAYSIA.DOSM. Retrieved 13 November 2016 from https://www.statistics.gov.my/index

[6] Deros, B. M., Hassan, N. H. H., Daruis, D. D. I., \& Tamrin, S. B. M. (2015). Incorporating Malaysian's Population Anthropometry Data in the Design of an Ergonomic Driver's Seat. Procedia-Social and Behavioral Sciences, 195, 2753-2760.

[7] Deros, B. M., Hassan, N. H. H., Daruis, D. D. I., \& Tamrin, S. B. M. (2015). Incorporating Malaysian's Population Anthropometry Data in the Design of an Ergonomic Driver's Seat. Procedia-Social and Behavioral Sciences, 195, 2753-2760.

[8] Dunk, N. M., \& Callaghan, J. P. (2005). Genderbased differences in postural responses to seated exposures. Clinical biomechanics, 20(10), 1101-1110.

[9] Ebe, K., \& Griffin, M. J. (2001). Factors affecting static seat cushion comfort. Ergonomics, 44(10), 901-921.

[10] Figà Talamanca, I., Cini, C., Varricchio, G. C., Dondero, F., Gandini, L., Lenzi, A., ... \& Patacchioli, F. R. (1996). Effects of prolonged autovehicle driving on male reproductive function: a study among taxi drivers. American journal of industrial medicine, 30(6), 750-758.

[11] Funakoshi, M., Tamura, A., Taoda, K., Tsujimura, H., \& Nishiyama, K. (2003). [Risk factors for low back pain among taxi drivers in Japan]. Sangyo eiseigaku zasshi= Journal of occupational health, 45(6), 235-247.

[12] Machin, M. A., \& De Souza, J. M. (2004). Predicting health outcomes and safety behaviour in taxi drivers. Transportation Research Part F: Traffic Psychology and Behaviour, 7(4), 257-270.

[13] Miyamoto, M., Konno, S., Gembun, Y., Liu, X., Minami, K., \& Ito, H. (2008). Epidemiological study of low back pain and occupational risk factors among taxi drivers. Industrial health, 46(2), 112-117.
[14] Mohamad, D., Deros, B. M., Daruis, D. D., Ramli, N. F., \& Sukadarin, E. H. (2016). Comfortable Driver's Car Seat Dimensions Based on Malaysian Anthropometrics Data. Iranian Journal of Public Health, 45(1), 106.

[15] Nahar, B. N., Ashan, G. U., \& Khan, N. A. (2013). Prevalence of low back pain and associated risk factors among professional car drivers in Dhaka city, Bangladesh. South East Asia Journal of Public Health, 2(1), 60-63.

[16] Herriotts, P. (2005). Identification of vehicle design requirements for older drivers. Applied ergonomics, 36(3), 255-262.

[17] Schneider, L. W. (1989). Survey of driver seating discomfort and related factors.

[18] Suruhajaya Pengangkutan Awam Darat -SPAD (2013), Retrieved 13 November 2016 from Source URL: http://www.spad.gov.my/ms/pengangkutan-awamdarat/teksi/statistik-utama

[19] Smith, D.B.D., Meshkati, N., Robertson, M.M., 1993. The older driver and passenger. In: Peacock, B., Karwowski, W. (Eds.),Automotive Ergonomics. Taylor and Francis, London, pp. 453-471.

[20] Raanaas, R. K., \& Anderson, D. (2008). A questionnaire survey of Norwegian taxi drivers' musculoskeletal health, and work-related risk factors. International Journal of Industrial Ergonomics, 38(3), 280-290.

[21] Rozali, A., Rampal, K. G., Shamsul Bahri, M. T., Sherina, M. S., Shamsul Azhar, S., Khairuddin, H., \& Sulaiman, A. (2009). Low back pain and association with whole body vibration among military armoured vehicle drivers in Malaysia. Med J Malaysia, 64(3), 197-204.

[22] Romli, A. (2009). Low back pain and association with whole body vibration among military armoured vehicle drivers in Malaysia.

[23] Robb, M. J., \& Mansfield, N. J. (2007). Self-reported musculoskeletal problems amongst professional truck drivers. Ergonomics, 50(6), 814-827.

[24] Tamrin, S. B. M., Yokoyama, K., Jalaludin, J., Aziz, N. A., Jemoin, N., Nordin, R., ... \& Abdullah, M. (2007). The association between risk factors and low back pain among commercial vehicle drivers in peninsular Malaysia: a preliminary result. Industrial health, 45(2), 268-278.

[25] Van Solinge H and Henkens K (2008) Adjustment to and satisfaction with retirement:Two of a kind? Psychology and Aging 23:422-434.

[26] Vink, P., \& Hallbeck, S. (2012). Editorial: Comfort and discomfort studies demonstrate the need for a new model.

[27] Wang, M. (2007). Profiling retirees in the retirement transition and adjustment process: examining the longitudinal change patterns of retirees' psychological well-being. Journal of Applied Psychology, 92(2), 455. 
[28] Yang, Y., Fan, X. S., Tian, C. H., Zhang, W., Li, J., \& Li, S. Q. (2014). Health status, intention to seek health examination, and participation in health education among taxi drivers in jinan, china. Iranian Red Crescent Medical Journal, 16(4).

[29] Yamazaki, N. (1992). Analysis of sitting comfortability of driver's seat by contact shape. Ergonomics, 35(5-6), 677692.

[30] Onawumi, A. S., \& Lucas, E. B. (2012). Ergonomic Investigation of Occupational Drivers and Seat Design of Taxicabs in Nigeria. ARPN Journal of Science and Technology, 2(3), 214-220.

[31] Park, S. J., Lee, Y. S., Nahm, Y. E., Lee, J. W., \& Kim, J. S. (1998). Seating physical characteristics and subjective comfort: design considerations (No. 980653). SAE Technical Paper.

[32] Pope, M. H., Magnusson, M., \& Wilder, D. G. (1998). Low Back Pain and Whole Body Vibration. Clinical orthopaedics and related research, 354, 241-248.

[33] Porter, J. M., \& Gyi, D. E. (1998). Exploring the optimum posture for driver comfort. International Journal of Vehicle Design, 19(3), 255-266.

[34] Xu, Y., Bach, E., \& Orhede, E. (1997). Work environment and low back pain: the influence of occupational activities. Occupational and Environmental Medicine, 54(10), 741-745.

[35] Zhang, L., Helander, M. G., \& Drury, C. G. (1996). Identifying factors of comfort and discomfort in sitting. Human factors, 38(3), 377-389. 